\title{
Обзоры
}

УДК $577.217: 337.32$

\section{Л. Л. Иванов}

\section{АМИНОАЦИЛ-тРНК СИНТЕТАЗЫ ВЫСШИХ ЭУКАРИОТ ПРИ ИЗМЕНЕНИЯХ СОСТОЯНИЯ ОРГАНИЗМА}

В обзоре обобиень зксперинентальные резильтаты изучения активности и своиств аминоачил-тРНК синтетаз (АРСаз) при различньх физиолосических и патологических со-стояниях восиих эукариотических организмов. Рассмотрень вопросы коррелячии между уровнем биосинтеза белка в органах и активностью АРСаз. Проанализированы даннье о стабильности высокомолекулярных комплексов АРСаз при изменении состояния организиа.

Аминоацил-тРНК синтетазы (АРСазы, КФ 6.1.1) играют важную роль в регуляции биссинтеза белка на уровне транслящии, катализируя высокоспецифическое аминоацилирование тРНК. Существенной особенностью, отличающей AРСазы высших эукариотических организмов от их аналогов из прокариот и низших эукариот, является способность некоторых из них образовывать высокомолекулярные комплексы между собой, а также с другими молекулами [1-4]. Присталыное внимание к таким комплексам, особенно в последнее десятилетие, определяется их предполагаемым значением для регуляции как активности $\Lambda$ РСаз, так и биосинтеза белка в целом.

Важной областью исследования АРСаз и их высокомолекулярных комплексов является анализ их активности и свойств при различных физиологических и патологических состояниях организма. Такой подход позволяет, с одной стороны, болсе детально изучить свойства этих ферментов и пути регуляции их активности, с другой--углубить по!имание причин и механизмов изменения интенсивности биосинтсза бслка при патольгиях. К настоящему времени опубликованы работы, посвященныс изучению свойств АРСаз при воздействии ряда бнологитсски активных веществ [5-18] и ионизирующей радиации [19-26], голодании животных $[6,27,28]$, развитии и старении организма $[19$, 29-39], изменении функционального состояния молочной железы [40, $41]$, регенерации печени [42-44], онкопатологиях $[33,45-51]$, нарущении кровообращения [52-60]. Это далеко не полный перечень и с каждым годом он увеличивается. Отдельные данные по этому вопросу суммированы в обзоре Данга [61].

Среди биологически активных вецеств, вызывающих нарушения в клеточном метаболизме, в том числе в биосинтезе белка, следует в первую очерсдь отметить гормоны. Тем не менее, их влияние на АРСазы изучено недостаточно. Показано, например, что введение кроликам инсулина приводит к значительному увеличению активности аланил- и валил-тРНК синтетаз в денервированных поперечно-полосатых мышцах [5]. Активность этих же АРСаз в интактных мышцах не меняется. Недостаточность инсулина, вызванная введением аллоксана, снижает аланил. и валил-тРНК синтетазные активности в денервированных мышцах [5]. Даму и соавт. [6] в экспериментах in vivo показали, что активность АРСаз высокомолекулярного комплекса печени крысы стимулируется инсулином и ингибируется глюкагоном. На основании полученных результатов авторы сделали вывод о том, что 
фосфорилирование АРСаз высокомолекулярного комплекса угнетает их активность, а дефосфорилирование - реактивирует. Такой же вывод следует из работы Берг, установившей увеличение активности 12 АРСаз лецсни мыши при введении эстрадиола [7]. Автор считает, что активация фосфатазы под действнем эстрадиола вызывает дефосфорилирование АРСаз и тем самым увеличивает их активность. Приведенные выше данные свидетельствуют об изменении активности АРСаз под действием гормонов. Однако пока нельзя однозначно утверждать, что это изменение является результатом только посттрансляционной 'модификации АРСаз, а ие вызвано другими причинами, как, например, изменениями в экспрессии генов этих ферментов.

В литературе есть сведения об ингибировании активности АРСаз различіыми токсинами. Так, угнетение процесса трансляции под действием микотоксина патулина, по мнению Арафата и соавт. [8], связано с обнаруженной инактивацией глутамил-, изолсйцил-, лейцил- и метионил-тРНК синтетаз высокомолекулярного комплекса печени овцы. Однако они не исключают ингибирующего влияния этого токсина и па другие компоненты белоксинтезируюшего аппарата клеток. Установленные изменения активности АРСаз носят обратимый характер, так как добавление антиоксиданта глутатиона полностью реактивирует исследуемые ферменты [8]. Другой микотоксин - афлатоксин $\mathrm{B}_{1}$, будучи канцерогенным соединением и индуцируя образовапие гепатомы у человека и животных, по данным Вагнера и Унтеррейнера [9], снижает уровень белкового синтеза в печени за счет ингибировапия активности АРСаз. Охратоксин А-микотоксин, вырабатываемый пекоторыми штаммами Aspargillus ochraceus и Penicillium viridicatum, ингибирует активность фенилаланил-тРНК синтетазы печени мыши и снижает уровень биосинтеза белка в культивируемых клетках гепатомы $[10,11]$. Его структурный аналог охратоксин В подобного эффекта не вызывает, но в то же время не ослабляет ингибирующего влияния охратоксина A [11]. Следует отметить, что не во всех случаях наблюдается корреляция между снижением уровня биосинтеза белка и активности АРСаз при воздействии ингибитора. Так, например, при полном блокировании трансляции в печени крысы циклогексимидом, а также при последуюшем ее восстановлении активность АРСаз практически не меняется [12].

Среди других биолопически активных веществ, подавляющих процесс транслящии, в том числе и активность АРСаз, можно упомянуть этанол [13-15], антибиотик боррелидин $[16,17]$, соединения ртути [18].

В ряде работ изучено влияние ионизирующей радиации на свойства АРСаз и их высокомолекулярных комплексов. Так, у эмбрионов кур спустя 24 ч после радиоактивного облучения обнаружено снижение активности валил-тРНК синтетазы [19], которое выражается как экспоненциальная функция от дозы облучения, причем фермент печени менее устойчив к действию ионизирующей радиации, чем фермент мозга [20]. Показано [21], что существует линейная корреляция между уменьшением активности валил-тРНК синтетазы и числа титруемых SH-групп. При действии рентгеновских лучей снижается термостабильность лизил-тРНК синтетазы печени крысы [22] и зарегистрированы ее конформационные изменения [23]. Данные работ [24, 25] указывают на то, что изменения АРСаз под действием радиоактивного облучения могут происходить за счет увеличения степени метилирова'ния ферментов. Высказано также предположение о том [26], что влияние радиации на активность АРСаз связано с нарушением процессов фосфорилирования - дефосфорилирования.

Определенный интерес представляют результаты, полученные при изучении эффекта голодания животных на активность АРСаз. Так, голодание крыс в течение ночи снижало на $50-60 \%$ активность аргинил-, изолейцил-, лейцил-, лизил- и метионил-тРНК синтетаз в составе высокомолекулярного комплекса печени [6]. Авторы связывают это 
явленис с увелицением соотношения глюкагон/инсулин, что, в свою очередь, приводит к повышению уровня фосфорилирования АРСаз. Выделениые из скелетных мышц нормальных и длительно голодавших кроликов аспартил-и валил-тРНК синтетазы различались по пространствснной структуре [27] и аминокислотному составу [18]. Авторы предположили, что обнаруженное снижение специфичности АРСаз, выделенных нз мышц длительно голодавших животных, является одной из причин синтеза белков с измененным аминокислотным составом при экстремальных состояниях организма [28].

Процессы голодания в определенной мере моделируются культивированием клеток на средах с дефицитом аминокислот. Уменьшенис концентрации мегнонина в среде от 100 до 1 мкM вызывало замедление роста культивируемых клеток янчника китайского хомячка, снижение скорости реацилирования метионил-тРНК и двукратное повышение содержания метионил-тРНК синтетазы в составе высокомолекулярного комплекса, установленное по данным иммунотитрования [62]. Содержанис других АРСаз комплекса при этом нс менялось. В клетках яичника китайского хомячка, выращенных при отсутствии в среде лейщина и изолейцина, активность глутамил-, изолейцил-, лейцил- и пролил-тPНК синтетаз в составе больших комплексов (30S) снижалась, а во фракциях с коэффициептом седиментации 6-10S и $10-22 \mathrm{~S}$ - увеличивалась [63]. Причину перераспределения АРСаз из тяжелого комплекса в более легкие фракции авторы не установили.

Глубокие измепения активности и свюйств: АРСаз происходят при развитин и старении организма. Валил-тPНК синтетаза из мозга 14дневного эмбриона кур менее чувствительна к радиоактивному облучению, чем фермент 18-дневного эмбрнона [19]. Лейцил-тРНК синтетаза из 7-днезных личинок Tenebrio molitor, в отличие от фермента одподневщых личинок, способна аминоацилировать новые изоакцепторныс лейциновые тРНК, появляющиеся в 7-дневном возрасте [29]. Авторы гредполагают, что этот фермент модифицируется во время развития личинок. Обнаружено, что в поджелудочной железе и мозжечкс взрослoro быка содержание триптофанил-тРНК синтетазы соответствснно в 100 и 10 раз больше, чем в органах новорожденного животного [30]. Активность АРСаз печени 1-2-летних кроликов выше по сравнению с новорожденными и понижается у 5-летних животных [31]. Наиболее выраженпое увеличение активности в печени 2-летних кроликов установлено для глицил-тРНК синтетазы, Результаты этой работы, как I данные других авторов $[61\}$, свидетельствуют о корреляции между повышением интснсивности биосинтеза белка в онтогенезс оргапизма и увсличением активности АРСаз.

С возрастом интенсивность белкового синтеза ослабевает, при этом отмечается снижение активности АРСаз в различных органах и тканях [32-34]. Одной из возможных причин такого явления может быть пакопление термолабильных форм ферментов, что установлено, например, для АРСаз из мозга, почек и печени стареющих мышей и крыс $[35,36]$. Обращает на себя внимание тот факт, что возрастание количества термолабильных ферментов связано с частичной диссоциацией высокомолекулярных комплексов АРСаз. Лейцил-тРНК синтетаза в тканях молодых крыс содержится в комплексах большего размера, чем в тканях старых животных [36]. Ннтересно и то, что диетическое кормление мышей предотвращает накопление термолабильных АРСаз в процессе старения [37]. В дальнейших исследованиях эти же авторы установили, что один из механизмов появления термолабильных ферментов связан с их модификацией в результа'те окисления [38].

Следует отметить, что снижение активности АРСаз в процессе старсния наблюдается не только в животных, нс и в растительных клетках. Так, например, активность хлоропластных и цитоплазматическнх лейцил-, тирозил- и фенилаланил-тPНК синтетаз значительно ниже в стареющих листьях бобовых, чем в зеленых [39]. Задержка старения листьев цитокининами приводила к повышению активности АРСаз. 
Резкое возрастание глутамил- и лейцил-тРНК синтетазных активностей обнаружено в молочной железе коров в период лактации [40, 41]. Это явление, как и увеличение содержания соответствуюших тРНК, авторы объясняют адаптацией наборов тPНК и $\mathrm{APCaз} \mathrm{к} \mathrm{сиі-}$ тезу специфических белков молока - казеинов, которые на $30 \%$ состоят из глугаминовой кислоты и лейцина. Более подробно этот вопрос рассмотрсн в монографии Ельской и соавт. [1].

Есть сведения об изменении свойств АРСаз в составе высокомолекулярных комплексов из регенерирующей печени, характеризующейся повышенным уровнем биосинтеза белков, что связано с высокой митогической активностью клеток. Авторы работы [42] установили повышение 15 АРСазных активностей из 17 исследованных в экстрактах печени крысы через 48 ч после частичнойі гепатэктомии. Возможно, что изменение АРСазиых активностей в регенерирующей печени зависит от перераспределения ферментов из низкомолекулярной фракции в высокомолекулярный комплекс, как это определено для пролил-тРНК синтетазы. Яремчук и соавт. [43] обнаружили повышение глутамил- и лизил-тРНК синтетазных активностей как в экстрактах ткани, так и в составе высокомолекулярных комплексов печени крысы через 21 ч после частичной гепатэктомии. На основании выявленного повышения метилтрансферазной и протеинкиназной активностей комплексов АРСаз сделано предположение о том, что изменение биосинтеза бслка при регенерации печсни связано с увеличением скорости отделылых этапов трансляции в результате модификации белков и нуклеиповых кислот, участвуюцих в этом процессе [44].

Удобной моделью для анализа изменения состояния организма являгтся мутантные линии клеточных культур. В мутантных клетках яичника китайского хомячка, чувствительных к повышению температуры, лейцил-тРНК синтетаза присутствует исключительно в виде свободной 8S формы, тогда как в клетках дикого типа этот фермент наряду со свободной формой присутствует в составе высокомолекулярных комплексов АРСаз с коэффициентом седиментации $20 \mathrm{~S}$ и $30 \mathrm{~S}[64$, 65]. На примере ревертантов термолабильного мутанта похазано, что по мере восстановления дикого типа в клетках появляются высокомолскулярные формы лейцил-тРНК синтетазы [66]. Кроме того, этот фермент в свободном состоянии в два раза термолабильгее и характеризуется более высоким значением $\mathrm{K}_{м}$ для лейцина, чем в составе высокомолекулярных комплексов. В некоторых других чувствительных к температуре линиях мутантных клеток ящчника китайского хомячка обнаружены разнонаправленные изменения активности АРСаз, специфичных для аргинина, глутаминовой кислоты, глутамина, гистидина, изолейцина, лейцина, валина, метионина, лизина и пролина [67]. При этом содержание некоторых ферментов в составе высокомолекулярных комплексов ниже по сравнению с клетками дикого тила. Активность лейцил-тРНК синтетазы в составе высокомолекулярного комплекса из мутантных клеток яичника китайского хомячка линии tsH1 значительно ниже, чем в комплексе из клеток дикого типа [68], однако в обоих типах клеток свободная форма фермента не обнаружена. Хампсл и соавт. [64] считают, что различие в формах АРСаз в мутантных клетках и клетках дикого типа может служить доказательством реального существования высокомолекулярных комплексов АРСаз в клетках высших эукариот.

Определенные изменения претерпевают АРСазы и их высокомолекулярные комплексы в опухолевых клетках. Так, показано, џто при лейкемии резко снижается специфическая активность АРСаз в селезенке и тонком кишечнике мыши и незначительно - в печени $[33,45]$, тогда как на ферменты легких, сердца и почек мыши [33], лейкоцитов мыши и человека [46] эта патология не оказывает заметного влияния.

Нскоторые авторы установили изменение содержания отдельных АРСаз в' составе высокомолекулярных комплексов, выделелных из опухолсвых клеток. В медленнорастущей гепатоме 7793 и быстрорастущей 
гспатоме АН130 отмечено перераспределение АРСаз из фракции свободных ферментов во фракцию высокомолекулярных комплексов [47, 48]. Болес того, в гепатоме крысы глутаминил-тРНК синтетаза обнаружена в комплексах с коэффициентами седиментации $28 \mathrm{~S}, 24 \mathrm{~S}$ и $18 \mathrm{~S}$, is то время как в нормальной печени этот фермент в основном содер. життся в $24 \mathrm{~S}$ комплексе [49]. По мнению авторов работ [47, 50], APСазы гепатомы ассоциированы в более стабильные структуры, чем фсрменты нормальных клеток. Специфическая активность аргинил- и метионил-тPHК синтетазы в 3-5 раз выше, а лизил-тРНК синтетазы в 2 раза ниже в комплексе, выделенном из трансформированных вирусом саркомы фибробластов мышей, по сравнению с комплексами нз нормалыных клеток [51]. Такое явление авторы связывают с возможной диссоциацией отдельных $\mathrm{APCa}$ из комплекса во время трансформации клеток вирусом, причиной чего может быть модификация фсрментов.

K значительным изменениям активности и свойств АРСаз приводит нарушение кровообрашения вследствие различных воздействий на сердечно-сосудистую систему. При этом отмечено угнетение бслоксинтезирующей функции как миокарда $[69,70]$, так и цругих органов, в том числе и печени $[71,72]$. Показано, что через 15 мин тотальной ишемин (аутолиза) в экстрактах миокарда свиньи увеличивается на $22-55 \%$ активность аланил-, глицил-, глутамил-, лейцил- и серилтPHK синтетаз [52, 53]. При $30-$ мин аутолизе происходит падение на $35 \%$ АРСазных активностей, за исключением аланил- и серил-тРНК синтетазных активностей, снижающихся до контрольного уровня. Похожие изменения активности АРСаз установлены при аноксии миокарда свиньи [54]. Активность АРСаз в составе высокомолскулярного комплекса (26-29S) через 15 мин аутолиза повышается на 25-98\%, а чсрез 30 мин аутолиза падает до уровня контроля, при этом из комплекса диссоциирует глицил-тРНК синтетаза [52]. Обнаружено, что при 15-мин аутолизе происходит частичное перераспределение лейцилrРНК синтетазной а'ктиности во фракцию высокомолекулярного комплекса (970 кДа), а прн 30 -мин - во фракцию свободного фермента [55].

Определенные изменепия АРСазных активностей при ишемических состояниях миокарда отмечены в печени животных. Так, через 6-24 ч после окклюзии коронарной артерии (ОКА) в экстрактах печени кротиков увеличивается активность ряда $\mathrm{APCa3,} \mathrm{в} \mathrm{то} \mathrm{время} \mathrm{как} \mathrm{акцептор-}$ гая активность соответствующих тРНК снижается [56]. Авторы считают, что повышение АРСазных активностей имеет компенсаторный характер и направлено на урегулирование белкового синтсза на его !пчальном этапе. В высокомолекулярных комплексах (26S), выделснных из печени кроликов через 12 ч после ОКА, наблюдалось увеличснис активности глутамил-, лейцил- и лизил-тРНК синтетаз и паденис - глицил- и серил-тРНК синтетаз за счет освобождения последних и переход в низкомолекулярную фракцию [57]. В этот же срок ОКА отмечено частичное перераспределение АРСазной активности из компілекса с молекулярной массой 1820 кДа в таковой 840 кДа [58], которое коррелирует с изменением скорости биосинтеза белка в бесклеточных системах из печени кроликов, содержащих эти АРСазные комплексы [59]. Приведенные выше сведения о возрастании лабильности больших высокомолекулярных комплексов АРСаз при ишемических состояниях миокарда подтверждают результаты работы [73], в которой указано на зиачительное перераспределение при ОКА тPHК-метилтрансфераз из состава АРСазного комплекса во фракцию свободных белков. Следует отметить и тот факт, что при ишемии миокарда установлено уменшенис активности некоторых АРСаз во фракции полирибосом печени. Это может быть связано с изменением компартмснтализацин ферментов на полирибосомах и явиться одной из причин иарушения биосинтеза белка при такой патологии $[60]$. 
Анализ литературных данных по изучению свойств АРСаз при различных состояниях организма указывает на их отрывочный характер, часто остаются неясными причины отличий в активности ферментов. Тем нс менее, в большинстве случаев изменение интенсивности биосинтеза белка в сргане сопровождается однонаправленным изменением активности АРСаз. Кроме того, в клетках и тканях с повышенным уровнем биосинтеза белка - гепатоме [47], регенерируюшсй печени [42], ревертантах термолабильного мутанта клеток яичника китайского хомячка [66] - отмечено увеличение стабильности высокомолекулярных комплексов АРСаз. При пониженном уровне биосинтеза белка - в печени, почках и мозге старых крыс [35, 36], в клетках яичника китайского хомячка, культивированных на среде с дефицитом некоторых аминокислот [63], в' термолабильном мутанте этих клеток $\lceil 64]$, в миокарде и печени животных при ишемии миокардэ $[52,55,57$, 58] - происходит частичная или полная диссоциация АРСаз из высокомолекулярного комплекса. Эти результаты позволяют предположить, что процессы ассоциации - диссоциации $\mathrm{APCaз} \mathrm{могут} \mathrm{играть} \mathrm{опреде-}$ пенную роль в регуляции скорости биосиптеза белка в эукариотичсских клетках.

Из данных некоторых работ $[35,36,55,66]$ можно заключить, что АРСазы в клетках с пониженным уровнем белкового синтеза отлитаются повышенной термолабильностью. Возможно, это также связано с частичной диссоциацией указанных ферментов из высокомолекулярных комплексов, так как есть сведения о том, что в их составе АРСазы более устойчивы к температурному воздействию, чем в свободном состоянии [74-76].

Summary. The experimental results on the higher eukaryotic aminoacyl-tRNA synthetases activity and properties in physiologic and pathologic states are summarized in present review. The correlation of protein biosynthesis level with aminoacyl-tRNA synthetase activity are discussed. The data on the stability of high-molecular-weight aminoacyl-tRNA synthetase complexes under alterations of organism state are analysed.

\section{СПИСОК ЛИТЕРАТУРЫ}

1. Резиляция биосинтеза белка у эукарионт / А. В. Ельская, Н. Ф. Стародуб, А. П. Потапов и др. - Киев: Наук. думка, 1990.-280 с.

2. Киселев $Л$. Л., Фаворова О. О., Лаврик О. И. Биосинтез бслков от амипокислот до аминоацил-тНК.- $\mathrm{M}$. : Наука, 1984.-408 с.

3. Dang C. V. Dang C. V. Multienzyme complex of aminoacyl-tRNA synthetases: an essence of being eukaryotic // Biochem. J.-1986.-239, N 2- - P. 249-255.

4. Mirande $M$. Aminoacyl-tRNA synthetase family from prokaryotes and eukaryotes: structural domains and their implications// Progr. Nucl. Acids. Res, and Mol. Biol.1991 - 40.- P. 95-142.

5. Усатенко M. C., Тесленко Л. B. Регуляция инсулином активности аминоащил-тНКсинтетаз в интактных и денервированных мышцах кролика// Биохимия.-1978.43. №12.- C. 2196-2199.

6. Damuni $Z$, , Caudwell $F$. B., Cohen $P$. Regulation of the aminoacyl-tRNA synthetase complex of rat liver by phosporylation in vitro and in vivo// Eur. J. Biocem.-1982.129, $\mathrm{N} 1 .-\mathrm{P} .57-65$.

7. Berg $B . H$. The early influence of $17-\beta$ oestradiol on 17 aminoacyl-tRNA synthetases of mouse uterus and liver. Phosphorylation as a regulation mechanism//Biochim. et biophys, actar.-1977. 479, N 2.-P. 152-171.

8. Arafat $W$. Kern D., Dirheimer $G$. Inhibition of aminoacyl-tRNA synthetases by the mycotoxin patulin // Chem.-Biol. Interact. - 1985. - 56, N 2-3.- P. 333-349.

9. Wagner $G$, Unterreiner A. M. Inhibition of rat liver aminoacyl-tRNA synthetases in vitro after acute and chronic aflatoxin $\mathrm{B}_{1}$ administration in wivo// Ibid.- 1981.37. N $1-2$ - P. 233-244.

10. Comparative study of the effect of ochratoxin $A$ analogues on ycast aminoacyl-tRNA synthetase and on the growth and protein synthesis of hepatoma cells $/ / \mathrm{E}$. E. Creppy, D. Kern, P. S. Steyn et al. // Toxicol. Lett.-1983.-19, N 2.- P. 217-224.

11. Influence of ochratoxin $\mathrm{B}$ on the ochratoxin $\mathrm{A}$ inhibition of phenylalanyl-1RNA formation in vitro and protein synthesis in hepatoma tissue culture cells $/ \Lambda$. Roth, E. E. Creppy, A. Kane et al. // Ibid -1989.-45, N 3.- P. 307-317.

12. Аминооиил-т РНК-синтетазные комплексы при резких изменениях биосинтеза белка А. Д. Яремчук, Н. И. Гончаров, О. Д. Багдонайте и др.// Докл. АН УССР. Сер. Б. $-1984 .-$ No 3.- C. $82-85$. 
13. О влиянии этанола на начальный этап биосинтеза белка в печени крыс / В. В. Сушкова, Н. Н. Касьянова, С. М. Васильева, М. Ф. Гулый // Вопр. мсд. химин.-1988.34, № 4.-C. $21-24$.

14. Суикова B. B., Касьянова $H$. . Н., Гульй $M$. Ф. Изменения начального этапа биосинтеза белка и аминоацил-тРНК-синтетазной активности в печени животных под дейсгвием этанола и ацетальдегида // Докл. АН УССР. Сер. Б.-1989.-№ 8.С. $81-83$.

15. Maenpaa P. H., Tewari $S$. A. A change in isoaccepting leucinc transfer RNA species in rat brain after prolonged ingestion of ethanol //Med. Biol._1983.-61, N 6.P. $313-318$.

16. Gant $S$. Bennett $C$. A., Arfin $S . M$. Increased levels of threonyl-tRNA synthetase in borrelidin-resistant Chinese hamster ovary cell line//Proc. Nat. Acad. Sci. USA. 1981.-78, N 9.-P. 5367-5370.

17. Gerken S. C., Arfin S. M. Chinese hamster ovary cells resistant to borrelidin overproduce threonyl-tRNA synthetase //J. Biol. Chem.-1984.-259, N 14.- P. 92029206.

18. Hasegawa K., Omata S., Sugano H. In vivo and in vitro effects of methylmercury on the activities of aminoacyl-tRNA synthetases in rat brain // Arch. Toxicol.-1988.62, N 6.- P. 470-472.

19. Bölöni $E$. Studies on the valyl-tRNA synthetase of chick cmbryo brain irradiated with ${ }^{\circ 0} \mathrm{Co} \gamma$-rays, in vivo // Int. J. Radiat. Biol.- $1980 .-37, \mathrm{~N} 1 .-\mathrm{P} .61-69$

20. Bölöni E. Batke J., Szabo L. D. Difference in radiosensitivity of valyl-tRNA synthetases isolated from chick embryo liver and brain // Ibid.- 1984.45, N 4.- P. 359369

21. Bölöni E. Valyl-tRNA synthetase from chick embryo brain. Properties of sulflıydryl groups // Acta biochim, et biophys. Acad. sci. hung.-1979-14, N 4.- P. 259-270.

22. Верхоглад $H$ H. Виноградова $P$. $I$. Кучеренко H. $E$ Изучсние кинстики термо11 нактивации лизил-тРНК-синтетазы из печени крыс лри действии рентгеновских лучей // Ра:циобнология.-1985.-25, № 2.-С. $185-190$.

23. Bлияние рснтгеновского облучения на люмннесцентные свойства лизнл-тРІІК синтетазы из печени крыс/И. Н. Верхогляд, А. И. Драган, Р. П. Виноградова, J. Е. Кучсренко // Там же.-1984.-24, № 6.- С. 748-752.

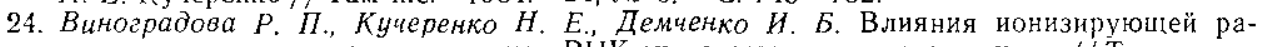
диапли на метилирование лизил-тРНК-синтетазы из печени крыс// Там же.1986.-26, № 1.- С. 88-91.

25. Слепџова Н. Л., Демиенко Н. Б., Виноградова Р. П. Свойства мстилтрансферазы мультнферментного комплекса аминоацил-тРНК синтетаз из печсни крыс//Пробл. общ. и молекуляр. биологин.-1985.- № 4.- С. $14-18$

26. Фосфорилирование лизил-тРНК-синтетазы из печени крыс под пействием рентгеновскнх лучсй // Р. П. Виноградова, Н. Е. Кучеренко, И. Н. Верхогляд, Н. В. Мирутенко // Радиобнология.-1982,-22, № 4._- С. 446-449.

27. Спектральные характеристики мышечных аспартил- и валил-тPІІК-синтетаз и комплексов с субстратами В норме и после длителыного голодания / В. Н. Глушак, А. П. Демченко, Н. Н. Орловская, М. Ф. Гулый // Укр. биохим. журн. $-1984 .-56$, № 5 .- С. $519-526$

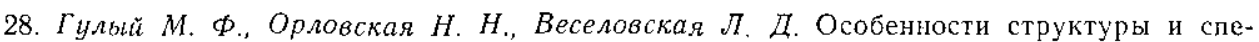
цифичности аспартил- и валил-тРНК-синтетаз мышечной ткани длительно голодавших кроликов // Там же.-1987.-59, № 5.- С. $32-36$

29. Ilan J., Ilan J. Similarities in properties and functional difference in purified leucyltRNA synthetase isolated from two developmental stage of Tenebrio molitor //Develop. Biol.-1975.-42, N 1.-P. 64-74.

30. Tryptophanyl-tRNA synthetase is a major soluble protein species in bovine pancrcas $/ M$. L. Sallafranque, $M$. Garret, J.-P. Benedetto et ai.// Biochim. et biophys. acta -1986 - $882, \mathrm{~N} 2$.- P 192-199.

31. Демидов C. B., Ельская A. В. Аминоацил-тРНҚ-синтетазная активность в ткани иечелін кроликов в онтогенезе // Укр. биохим. журн.-1980.-52, № 1.-C. 75-78.

32. Bublitz $C$. Some properties of proline-sRNA synthetase from $r$ at liver//Biochim. et biophys. acta.-1966.-128, N 1.- P. 165-171.

33. Aminoacyl-tRNA synthetases in liver, spleen and small intestine of aged leukemic and aged normal mice/H.-J. Gabius, S. Gabius, G. Graupner et al.// Z. Naturforsch.1983.-38, N 9-10.- P. 881-882.

34. Gabius H.J., Graupner G., Cramer F. Activity patterns of aminoacyl-tR: ${ }^{\text {A }}$ synthetases, tRN $\Lambda$ methylases, arginyltransferase and tubulin: tyrosine ligase during development and ageing of Caenorhabditis elegans//Eur. J. Biochem.-1983,-131, N 1 - P. 231-234.

35. Takahashi R., Mori N., Goto S. Alteration of aminoacyl-tRNA synthetases with age: accumulation of heat-labile enzyme molecules in rat liver, kidney and brain $/ /$ Mech. Agcing and Develop.-1985.-33, N 1.- P. 67-75.

36. Takahashi R., Goto S. Aga-associated accumulation of heat-labile aminoacyl-tRNA synthetases in mice and rats//Arch. Gerontol. Geriatr. - 1987. - 6, N 1. - P. $73-82$.

37. Goto S., Takahashi $R$. Accumulation of heat-labile aminoacyl-tRNA synthetases and effects of dietary restriction in aged mice// Age.-1987.-10, N 3.- P. 120 .

38. Takahashi R., Goto S. Alteration of aminoacyl-tRNA synthetase with age: heat-labilization of the enzyme by oxidative damage//Arch. Biochem. and Biophys.1990.-277, N 2.- P. 228-233. 
39. Variations in the levels of chloroplast tRNAs and aminoacyl-tRNA synthetases in semescing leaves of Phaseolus vulgaris/C. Jayabaskaran, M. Kuntz, P. Guillemaut, J-H. Weil // Plant. Physiol.-1990.-92, N 2.-- P. 136-140

40. $t R N A$ and aminoacyl-tRNA synthetases during differentiation and varions functional states of the mammary gland // A. V. El'skaya, G. Kh. Malsuka, U. Matiash ct al.// Biochim. et biophys, acta- $-1971 .-247$, N 3.-P. $430-440$

41. El'skaya A. V. Transfer RNA and aminoacyl-tRNA synthetases in the regulation of protein biosynthesis at translational level// Sov. Sci. Rev. D. Physicochem. Biol.1988.-28, N 1.-P. $149-184$.

42. Effects of liver regeneration on tRNA contents and aminoacyl-sRNA synthetase activities and sedimentation patterns/U. del Monte, S. Capaccioli, G. Neri Cini et al. // Biochem. J. $-1986 .-236, \mathrm{~N}$ 1.-P. $163-169$.

43. Aниноацил-т РНК-синтетазы и пх высокомолекулярные комплексы из регенериру. ющей печени крыс // А. Д. Яремчук, Л. Э. Тарасявнчене, Т. П. Кондратюк, А. В. Ельская // Молскуляр. биология.-1984-18, № 5.- С. $1336-1341$.

44. Нзуtение функциональной роли высокомолекулярных комплексов аминоацил-тPІІК синтетаз / А. В. Ельская, А. Д. Яремчук, Н. И. Гончаров, О. В. Булдакова // Пробл. саврем. биохимии и биотехнологии : Тез. докл. 8 объед. симпоз. биохим. об-в СССР - ГДР.- Рига, 1985- - С. $169-170$.

45. Aminoacyl-tRNA synthetases in ageing and leukemia (EC 6.1.1)/H.-J. Gabius, S. Goldbach, G. Graupner et al.//Hoppe-Seyler's Z. Physiol. Cliem.-1982. 363, N 9.- P. 874

46. Agris P. F., Wolverton D. K., Setzer D. Subcellular localization of $S$-adenosyl- $l$ methionine: tRNA methyltransfcrases with aminoacyl-tRNA synthetases in humau and mouse: normal and leucemic leucocytes// Proc. Nat. Acad. Sci. USA.-1976.73, N 11.- P. 3857-3861.

47. Stadies on particulate and soluble forms of aminoacyl-tRNA synthetases from rat liver and hepatomas / U. del Monte, G. Neri Cini, S. Capaccioli et al. // Med. Biol. Environ.-1981.-9, N 1.-P. 375-379.

48. Perego R., del Monte U. Allotropism in aminoacyl-tRNA synthetases from Yoshida hepatoma AH130 // IRCS Med. Sci.-1982.-10.- P. 536-537.

49. Del Monte U., Perego R. Multiple forms of giutaminyl-tRNA synthetase in rat hepatoma induced by 4-dimethylaminoozobenzene // Med. Biol. Environ. - 1983.-11, $\wedge 1 .-$ P. $151-156$.

50. Perego R., del Monte $U$. A stable complex from Yoshida ascites hepatoma $\mathrm{AH} 130$ containing nine aminoacyl-tRNA synthetases // Cell. Biol. Int. Rep. - 1986.-10, N 6.- P. 477 .

51. Composition of complexes containing lysyl-tRNA synthetase from normal and virustransformed cells $/ \mathrm{K}$. Thomas, K. Scheets, S. Allen, C. Hedgcoth $/ /$ Canad. J. Biochem. - 1982.-60, N 8.- P. 804-810.

52. Aлиноаиил-т РНК синтетазы и их высокомолекулярные комплексы при аутолнзе сердца свиныг / А.-А. Й. Тамулявичюс, Л. Л. Иванов, Л. Ю. Лукошявичюс и др. // Вопр. мед. химин - 1985-- 31, № 5.-С. 104-107.

53. Аминоацил-тPНК-синтетазы и их высокомолекулярные комплексы при экспериментальном инфаркте миокарда/Л. Л. Иванов, А.-А. И. Тамулявичюс, Л. Ю. Лукошявичюс и др. // Молекуляр. биология. $1984-18$, № 5-C. 1326-1329.

54. Биологическая активность тРНК и аминоацил-тРНК-синтетаз миокарда свиньи при аноксии и последующей реоксигенации /А. П Қашаускас, А.-А. И. Тамулявичюс, Л. Ю. Лукошявичюс и др. // Вопр. мед. химин.- 1988.-34, № 2.- С. $84-86$.

55. Нзучение свойств лейцил-тРНК-синтетазы из миокарда свиньи в лорме и при экспериментальной ишемии $/$ Р. Р. Стапуленис, Л. Л. Иванов, Л. Ю. Лукошявичюс и др. // Там же.-1989.-35, № 4.- С. 56-60.

56. РPHК и аминоацил-тРНК синтетазы печени кроликов при эксперимснтальном инфаркте миокарда / Л. Ю. Лукошявнчюс, Г. А. Родовичюс, М. И. Қоваленко и др. // Там же.-1983.-29, № 4.- С. $65-69$.

57. Изучение комплексов аминоацил-тРНК синтетаз печени кроликов при экспсриментальном инфаркте миокарда /Л. Л. Иванов, Л. Ю. Лукошявичюс, М. И. Коваленко и др. // Укр. биохим. журн.-1983.-55, № 4.- С. $368-371$.

58. Pacnределенuе аминоацил-тРНК-синтегазной активности в клетках печени кроликов при нарушении биосинтеза белка в условиях экспериментального инфаркта миокарда / Л. Л. Иванов, 3. П. Мартинкус, А. В. Лекис и др.// Там же.-1989.-61, № 2.- С. $34-38$.

59. Роль аминоацил-тРНК-синтетаз в изменении скорости биосинтеза белка в печсли кроликов при ишемин миокарда/3. П. Мартинкус, Л. Л. Иванов, А. В. Лекис, А. К. Прашкявичюе // Бюл. эксперим. биологии и медицины.—1990.-59, № 6.C. $563-565$.

60. Нзичение взаимодействия эукариотических аминоацил-тРНК-синтстаз с полирио̆осомами / 3. П. Мартинкус, Л. Л. Иванов, А. В. Лекис и др.// Вопр. мсд. химии.$1990 .-36$, № 5.- C. 6-8.

61. Dang C. V., Dang $C$. V. Higher eukaryotic aminoacyl-tRNA synthetases in physiologic and pathologic states// Mol. and Cell. Biochem.-1986.-71, N 2.- P. 107120 .

62. Lazard M.. Mirande M., Waller J.-P. Expression of the aminaacyl-tRNA synthetase complex in cultured Chinese hamster ovary cells. Specific derepression of the methionyl-tRNA synthetase component upon methionine restriction //J. Biol. Chem, 1987.-262, N 9.- P. 3982-3987. 
Q.3. Enger M. D., Ritter P. O., Hampel A. E. Alteted aminaacyl-tRNA synthetase com. plexes in $\mathrm{G}_{1}$-arrested Chinese hamster ovary cells // Biochemistry. — — 1978.--17, N 12 - - P. $2435-2438$

64. Hampel A. E., Ritter P. O., Enger M. D. A physically altered leucyl-1RNA synthetase complex in CHO cell inutant// Nature.- 1978. - 276, N 5690.-P. 844-845.

65. A Chinese hamster ovary leucyl-tRNA synthetase mutant with uniqueli altered high molecular weight leucyl-tRNA synthetase complex / A. Mansukhani, T. Condon, $\Lambda$. Hampel, D. L. Oxender // Biochem. Genet.-1984.-22, N 3-4.- P. 349-354.

66. Klekamp M., Pahuski E., Hampel A. Reformation of lcucyl-tRNA synthetase complexes in revertants from $\mathrm{CHO}$ mutant tsH1// Somat. Celi. Genet.-1981.-7, N 6.P. $725-735$

67. Altered aminoacyl-tRNA synthetase complexes in CHO cell mutants/E. Paluski, M. Klekamp, T. Condon, $\Lambda$. E. Hampel// J. Cell, Physiol.-1983.-114, N 1.- P. 8287.

68. Mirande M., Le Corre D., Waller J.-P. A complex from cultured Chinese hamster ovary cells containing nine aminoacyl-tRNA synthetases. Thermolabile leucyl-tRN $A$ sy!thetase from the tsHl mutant cell line is an integral components of this complex $/ /$ Eur.. J. Biochem.-1985.-147, N 2.- P. 281-289.

69. Масколюнас Р. К., Лекис А. В., Коваленко М. И. Биосинтез белка в бесклстопных блокситезирующих системах из миокарда кролика при тотальной ишемии // Бионолимсры и клетка.-1989.-5, № 1.- С. 84-86.

70. Kašauskas A., Tamulevičius A.-A., Rodovičius $H$. Protein synthesis in anoxic pig myocardium // J. Mol. and Cell. Cardiol.-1990.-22, Suppl. 3.- P. 66.

71. Белоксинтезирноцая функция печени кроликов при экспсриментальном инфаркте миокар:да / А. В. Јекис, О. В. Будлакова, М. И. Коваленко и др. // Бюл. экспсрим. бнологии и меднцин.-1985.-49, 으 1.- С. $57-60$.

72. Bлияние культнвируемых клеток полисциаса па биосинтез белка в псчели кролнжов / А. В. Лекис, Т. К. Машанаускас, Л. Л. Иванов и др. // Хим.-фарм. журн.1988.-22, № 8.- C. $970-973$.

73. Сравнительные характеристики тРНК-метилтрансфераз печени и миокарда кроликов в норме и при экспериментальной ишемии / Л. Э. Тарасявичене, А. А. Ясайтис, IL. В. Рачяускайте и др. // Биохимия.-1989.-54, № 3.- С. 427-433.

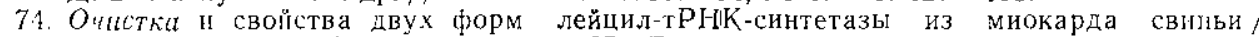
Р. Р. Стапуленис, Л. Л. Иванов, Л. Ю. Лукошявичюс и др.// Биополимеры и клетка. - 1986.-2, № 6. - C. 302-307

75. Dang C. V. High molecular weight complex formation of rat liver lysyl-tRNA synthetase reduces enzyme labilty to thermal inactivation//Biochem. and Biophys. Res. Conmuns.- 1982.- 106, N 1.- P. 44-47.

76. Molnar S. J., Rauth $A . M$. The eftect of amino acids on the temperature sensitive phenotype of the mammalian leucyl-tRNA synthetase mutant tsHl and its revertants// J. Cell. Physiol.-1979.-98, N 3.- P. 315-326.

Ин-т молскуляр. биологии и генетики

Получено 02.04 .92

АІ У 